\title{
PHYSICAL AND CHEMICAL PROPERTIES OF AN OXISOL AFTER MAIZE CROPPING ON ROTATION WITH LEGUMINOUS PLANTS
}

\author{
PROPRIEDADES FÍSICAS E QUÍMICAS DE UM LATOSSOLO VERMELHO \\ DURANTE O CULTIVO DO MILHO APÓS ROTAÇÃO COM PLANTAS \\ LEGUMINOSAS
}

\section{Danielle Medina ROSA ${ }^{1}$; Lúcia Helena Pereira NÓBREGA ${ }^{2}$; Márcia Maria MAULI ${ }^{3}$; Gislaine PICCOLO de LIMA ${ }^{4}$; Ariane SPIASSI ${ }^{5}$; Adriana Maria MENEGUETTI ${ }^{6}$}

\begin{abstract}
${ }^{1}$ Bióloga, Pós-doutorado pelo Programa de Pós-Graduação em Engenharia Agrícola, da Universidade Estadual do Oeste do Paraná, Cascavel/PR, e-mail: danimrosa@ yahoo.com.br. ${ }^{2}$ Engenheira Agrônoma, Doutora, Docente do Programa de Pós-Graduação em Engenharia Agrícola da Universidade Estadual do Oeste do Paraná, Cascavel/PR, email: luciahpn@ gmail.com. ${ }^{3}$ Bióloga, Pós-doutorado pelo Programa de Pós-Graduação em Engenharia Agrícola da

Universidade Estadual do Oeste do Paraná, Cascavel/PR, e-mail: marcia.m.mauli@gmail.com. ${ }^{4}$ Bióloga, Pósdoutorado em Conservação e Manejo de Recursos Naturais da Universidade Estadual do Oeste do Paraná, Cascavel/PR, e-mail: gisalipi@ yahoo.com.br. ${ }^{5}$ Bióloga, Doutora pelo Programa de Pós-Graduação em Engenharia Agrícola da Universidade Estadual do Oeste do Paraná, Cascavel/PR. CEP 85819-110, e-mail: arispiassi@hotmail.com. ${ }^{5}$ Pós-doutorado em Engenharia Agrícola, Professora Adjunta Universidade Tecnológica Federal do Paraná, Santa Helena/PR, e-mail: adrianam@utfpr.edu.br.
\end{abstract}

\begin{abstract}
Crop rotation has been a daily management to ensure viability of no-tillage system; however, it is few accepted and practiced by farmers. Thus, this study aims to establish a crop rotation scheme in soil quality. Consequently, cover crops of dwarf mucuna, pigeon pea dwarf, sun hemp and maize were cropped in 2010 under no-tillage system. Soil properties were determined prior their beginning, after the management of cover crops and maize harvest. Results were submitted to ANOVA and averages were compared. The macroporosity and total porosity answered to the adopted management with some variation. So, cover crops need much time to express their potential, mainly related to the physical characteristics of the studied soil. Chemical properties are susceptible to this management since higher changes were observed after management with cover crops. This crop rotation in a long term may allow the maintenance of soil quality because it avoids losses of nutrients and carbon.
\end{abstract}

KEYWORDS: Crop rotation. Humic substances. Zea mays. Mucuna deeringiana. Cajanus cajan. Crotalaria juncea.

\section{INTRODUCTION}

The inadequate farming systems, intensive, with monoculture or crop succession, degrade organic matter and change soil properties. This unbalances the agricultural system which results in lower productivity. Besides, they cause and/or intensify the environmental damage. In this regard, no-tillage system is considered the nearest one to sustainability.

In Paraná State, the no-tillage system is widespread, however, the appropriate practices have been forgotten over years. There is also an absence of discipline by farmers to carry out the recommended techniques, mainly crop rotation, which impairs the whole system. In a short term, it can be inferred that the best rotation for system is not the most economic for them.

Proper management of no-tillage system requires the use of cover crops rotation with important agricultural crops, which are viable when can contribute to the improvement of chemical, physical and biological soil properties. There are also reductions on weed population, application inputs and consequently an increase on crops productivity and stability. The feasibility of choosing cover crops species should be understood as an essential component to the development of notillage quality, towards a sustainable agriculture (CALEGARI, 2006; MINGOTTE, 2014; COSTA et al., 2016).

The greatest obstacle for farmers is because they defend that cover crops compete with other 
important crops in area compromising their income. Thus, crop rotation must include different species of cover crops, adapted to regional conditions and distributed in time and space. They get adapted to farmers' socio-economic conditions, interests, and are economically viable. FRANCHINI et al. (2011) have stated that the technical assistance and farmers must consider crop rotation as an investment in farm, whose income will occur in medium and long term.

So, the recommendation of species to take part of crop rotation scheme should always be considered, as well as the history of area, soil, weather and phytosanitary conditions. Agricultural productivity and profitability must be reached in order to always keep biodiversity and environment preservation, with continuous supply of organic material to soil, at medium and long terms, so that it can be possible to maintain or recover its fertility.

Considering the importance of crop rotation, associated with the direct sowing, for a sustainable agricultural practice, improve and/or maintain the properties of soil, either in fertility, porosity or carbon dynamics, this study aimed to analyze the soil characteristics for maize cropped in rotation to cover crops such as dwarf mucuna, dwarf pigeon pea and sunn hemp.

\section{MATERIAL AND METHODS}

\section{Location and characterization of the experimental area}

The experiment was carried out in a farm at coordinates $24^{\circ} 54^{\prime} 08^{\prime \prime} \mathrm{S}$ latitude and $53^{\circ} 07^{\prime} 15^{\prime \prime} \mathrm{W}$ longitude, with 643-meter altitude. The soil is classified as Dystrophic red eutrophic Oxisoil. The climate is humid subtropical (Cfa ), with 1800-mm annual average rainfall, hot summers, rare frosts and trend of rainfall concentration in summertime without dry season. The average temperature is 20 ${ }^{\circ} \mathrm{C}$ and $75 \%$ relative humidity.

\section{History of area management}

The experimental area was cropped under no-tillage system with soybean (Glycine max) succession in summer and wheat (Triticum aestivum) in winter for approximately ten years. In the experiment carried out by Rosa et al. (2011) and Rosa et al. (2013), in 2007/2008 agricultural year in the same area, the soil was prepared under minimum tillage (chiseling + light disking), because the studied soil was under compaction. It was also applied limestone. In 2008/2010 years, the area was cropped again with wheat/soybean succession.
Thus, this experiment was carried out on wheat crop residues under no-tillage system.

\section{Experimental conditions and treatments}

Leguminous as dwarf mucuna (Mucuna deeringiana), dwarf pigeonpea (Cajanus cajan) and sunn hemp (Crotalaria juncea) were settled in an experimental area in September 2010, in 4 x $5 \mathrm{~m}$ plots, with one meter distance between plots, sown without fertilization, under no-tillage system. There were four treatments, composed of three leguminous and a control (fallow). At the end of vegetative stage and early flowering, samples were collected from plants for laboratory tests and the rest was brushed with a mechanical cutter. So that crop residues remain on each corresponding plot to the treatment.

Maize was cropped according to the treatments distribution scheme already used in the previous experiment with leguminous. The treatments were control/maize, dwarf mucuna/maize, dwarf pigeon pea/maize and sunn hemp/maize. The control received the same management than the other treatments, but the area remained under fallow (natural vegetation). Maize was sown by hand in January 2011 on leguminous plant residues (15 days after management) and control, in demarcated plots under no-tillage system. The rows spacing was $80 \mathrm{~cm}$, with a density of six seeds per meter. Fertilization was carried out with $350 \mathrm{~kg} \mathrm{ha}^{-1}$, at sowing of 10-20-20 (N- $\left.\mathrm{P}_{2} \mathrm{O}_{5}-\mathrm{K}_{2} \mathrm{O}\right)$ formula and $140 \mathrm{~kg} \mathrm{ha}^{-1}$, at coverage, of urea $(60 \mathrm{~kg}$ $\mathrm{ha}^{-1}$ of nitrogen).

\section{Determination of soil properties}

Soil properties were determined before and after cover plants management and after maize harvest. Samples for soil chemical characterization were taken at 0 to $20 \mathrm{~cm}$ depth, in each plot, which were mixed to obtain a compost sample for treatment. The analyses were performed at the Central Cooperative for Agricultural Research COODETEC.

Physical properties were determined by collecting no deformed samples of soil, with a volumetric ring, according to Kiehl methodology (1979) and EMBRAPA (1997). The bulk density was determined on the same day of water content determination. Total porosity, macro and microporosity of soil were determined from the same samples collected for soil bulk density.

Macropores were determined in a special table under $60 \mathrm{~cm}$ water column (KIEHL, 1979). Water was extracted from macropores of a previously saturated sample. Micropores were determined by drying the sample at $105^{\circ} \mathrm{C}$. 
The total soil carbon was determined by ignition from burning in a muffle at $440 \pm 5{ }^{\circ} \mathrm{C}$ of a pre-dried material in a greenhouse at 105 to $110^{\circ} \mathrm{C}$, according to ISO 13600 recommendations. Data were expressed by percentages of both total organic carbon and organic matter.

Humic substances - fulvic acids (FA), humic acid (HA) and humin (HU) fractions - were determined at the same occasions, according to Benites, Madari and Machado (2003) methodology. Relationships were calculated between humic acid and fulvic acids fractions (HA:FA) and the ratio between the soluble fractions (FA + HA) in alkaline extract $(\mathrm{AE})$ and the residue (humin $-\mathrm{H}$ ) in order to obtain $\mathrm{AE}: \mathrm{H}$.

\section{Statistical analysis}

The experimental design was completely randomized with five replications per treatment, totaling 20 plots. The results were submitted to analysis of variance and average comparison by Scott- Knott test at 5\% probability. Some variables were submitted to correlation.

\section{Results and discussion}

Microporosity and soil bulk density values did not vary significantly among the treatments (Table 1). Although the increase in pore has been expected when using management with cover crops, biological pores represent less than $3 \%$ volume of soil and their formation reduces in a little way density, however, in air and water flows concerning profile, they have a major effect, often undetected by traditional methods (Reinert et al., 2008). It must be considered that the soil structure can be altered by agricultural use (MAZURANA, et al., 2017).

Table 1. Macroporosity, microporosity and total porosity, soil bulk density and water content before and after management with plant dwarf mucuna (Mucuna deeringiana), pigeonpea dwarf (Cajanus cajan) and sunn hemp (Crotalaria juncea) and weeds in the control and after maize harvest

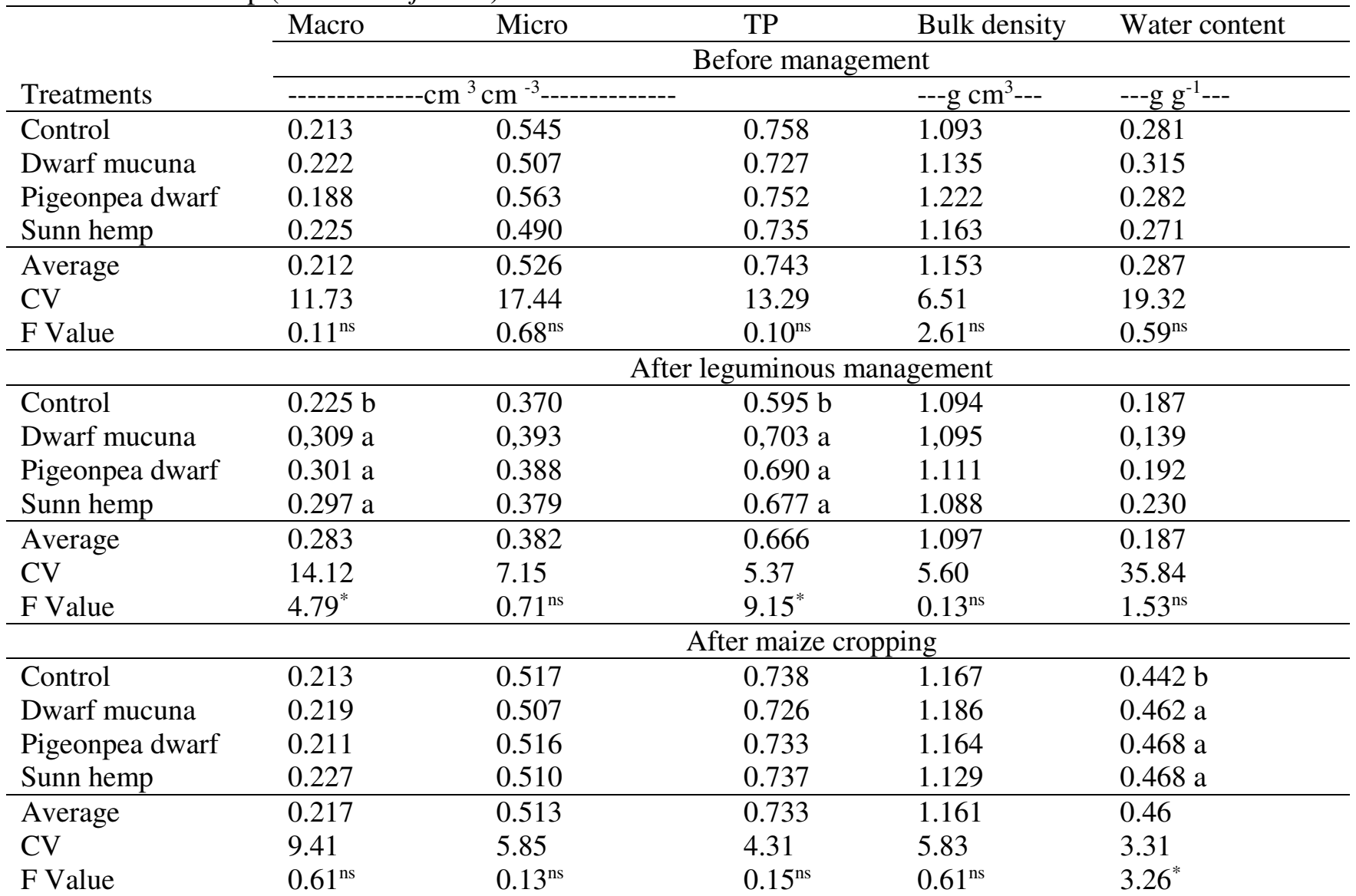

Averages followed by letters in column differ by Scott- Knott test at $5 \%$ probability. ns = no significant; * = significant. Data that did not show normality by Shapiro-Wilk test were transformed by $\sqrt{x+0,5}$. CV $=$ Coefficient of variation. TP $=$ total porosity. Macro $=$ macroporosity. Micro = microporosity.

At the beginning of this experiment, there was no statistical difference among the treatment averages. However, after the management of cover crops, there was a change in pore diameter, and the plots cropped with 
cover crops showed an increase in macroporosity and total porosity values. During this period, the treatments with sunn hemp, dwarf mucuna and dwarf pigeon pea cover plants increased at 32,37 and $60.1 \%$ in soil macroporosity, respectively, when compared to the control. It is important to highlight that leguminous root system reaches great depths and can take part of a greater volume of soil. It also allows physical recovery of compacted soils; consequently new biopores come out by root system (AMBROSANO et al., 2005).

Another aspect to be considered is that bulk density is not a limiting factor in yield in this management system, in none of the treatments and periods. Since the obtained values ranged from 1.065 to $1.226 \mathrm{~g} \mathrm{~cm}^{-3}$, which are considered inferior to the limiting one for the plants $\left(1.30 \mathrm{~g} \mathrm{~cm}^{-3}\right)$ (KLEIN, 2006) .

Soil macroporosity values were also higher than the considered limiting answer for maize, which is $0.10 \mathrm{~cm}^{3} \mathrm{~cm}^{-3}$. This value is considered the least porosity for gaseous and liquid exchanges between the external environment and soil. After maize harvest, the difference was observed in soil water content, and the control showed the lowest value. This may be due to the addition of organic matter which increases water retention capacity in soil. This is mainly because the fraction presented by humus and organic matter can hold four to six times more water than its own weight and, as a practical result, it can reduce erosion (MIYASAKA et al., 2008).

Besides, both content and soil organic matter composition influence structure and adsorptive properties of soil, water retention is also changed when changes occur in soil organic matter with management practices (SILVA; MENDONÇA, 2007). Similar results were found out in soil chemical analysis as major changes were observed after management with cover crops (Table 2).

Table 2. Soil chemical analysis before and after management with dwarf mucuna (Mucuna deeringiana), dwarf pigeon pea (Cajanus cajan) and sunn hemp (Crotalaria juncea) and weeds in the control and after maize harvest

\begin{tabular}{|c|c|c|c|c|c|c|c|c|c|c|c|c|c|c|}
\hline \multirow[b]{3}{*}{ Treatment } & \multicolumn{14}{|c|}{ Before management } \\
\hline & $\mathrm{C}$ & $\mathrm{K}^{+}$ & $\mathrm{Ca}^{2+}$ & $\mathrm{Mg}^{2+}$ & $\begin{array}{l}\mathrm{H}^{+}+ \\
\mathrm{Al}^{3+}\end{array}$ & BS & CEC & $\mathrm{P}$ & $\mathrm{Zn}$ & $\mathrm{Fe}$ & $\mathrm{Mn}$ & $\mathrm{Cu}$ & $\mathrm{pH}$ & V \\
\hline & $\mathrm{g} \mathrm{dm}^{-3}$ & \multicolumn{12}{|c|}{ 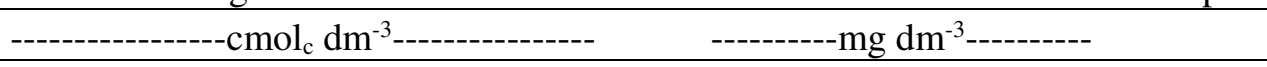 } & $\%$ \\
\hline Control & 17 & 0.4 & 4.2 & 2.1 & 4.9 & 6.7 & 11.6 & 7.6 & 3.5 & 40 & 130 & 17.0 & 5.1 & 58 \\
\hline D. mucuna & 17 & 0.3 & 4.2 & 2.6 & 4.6 & 7.2 & 11.8 & 5.4 & 2.7 & 48 & 121 & 16.4 & 5.3 & 61 \\
\hline P. dwarf & 17 & 0.4 & 4.6 & 2.2 & 4.9 & 5.9 & 12.3 & 41 & 4.2 & 41 & 137 & 14.3 & 5.2 & 59 \\
\hline \multirow[t]{4}{*}{ Sunn hemp } & 17 & 0.4 & 4.3 & 2.0 & 4.9 & 6.8 & 11.8 & 19 & 4.8 & 40 & 100 & 15.5 & 5.2 & 58 \\
\hline & \multicolumn{14}{|c|}{ After leguminous management } \\
\hline & $\mathrm{C}$ & $\mathrm{K}^{+}$ & $\mathrm{Ca}^{2+}$ & $\mathrm{Mg}^{2+}$ & $\begin{array}{l}\mathrm{H}^{+}+ \\
\mathrm{Al}^{3+} \\
\end{array}$ & $\mathrm{BS}$ & $\mathrm{CEC}$ & $\mathrm{P}$ & $\mathrm{Zn}$ & $\mathrm{Fe}$ & $\mathrm{Mn}$ & $\mathrm{Cu}$ & $\mathrm{pH}$ & $\mathrm{V}$ \\
\hline & $\mathrm{g} \mathrm{dm}^{-3}$ & \multicolumn{12}{|c|}{-- } & $\%$ \\
\hline Control & 21 & 0.8 & 6.0 & 2.4 & 4.2 & 9.3 & 13.6 & 19 & 4.8 & 13 & 176 & 11.2 & 5.5 & 68 \\
\hline D. mucuna & 24 & 1.1 & 6.2 & 2.9 & 3.6 & 10.3 & 14.0 & 29 & 3.9 & 19 & 173 & 9.5 & 5.7 & 73 \\
\hline P. dwarf & 23 & 1.1 & 6.3 & 2.7 & 3.4 & 10.2 & 13.6 & 18 & 4.2 & 19 & 176 & 9.9 & 5.8 & 75 \\
\hline \multirow[t]{4}{*}{ Sunn hemp } & 26 & 1.1 & 7.2 & 2.9 & 3.6 & 11.3 & 15.0 & 22 & 4.2 & 20 & 226 & 11.7 & 5.7 & 75 \\
\hline & \multicolumn{14}{|c|}{ After maize cropping } \\
\hline & $\mathrm{C}$ & $\mathrm{K}^{+}$ & $\mathrm{Ca}^{2+}$ & $\mathrm{Mg}^{2+}$ & $\begin{array}{l}\mathrm{H}^{+}+ \\
\mathrm{Al}^{3+}\end{array}$ & BS & CEC & $\mathrm{P}$ & $\mathrm{Zn}$ & $\mathrm{Fe}$ & $\mathrm{Mn}$ & $\mathrm{Cu}$ & $\mathrm{pH}$ & $\mathrm{V}$ \\
\hline & $\mathrm{g} \mathrm{dm}^{-3}$ & $-\cdots$ & -1---- & $---\mathrm{cmol}$ & $\mathrm{dm}^{-3}$ & $\begin{array}{ll}----- \\
-\cdots\end{array}$ & & ----- & $---m_{1}$ & $\mathrm{dm}^{-}$ & 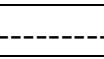 & & & $\%$ \\
\hline Control & 19 & 0.4 & 5.4 & 1.9 & 4.9 & 7.8 & 12.8 & 9.6 & 2.7 & 23 & 113 & 13.5 & 5.2 & 61 \\
\hline D. mucuna & 17 & 0.4 & 4.5 & 1.7 & 4.9 & 6.7 & 11.6 & 14.0 & 2.7 & 26 & 96 & 13.5 & 5.1 & 58 \\
\hline P. dwarf & 19 & 0.4 & 5.1 & 2.1 & 4.6 & 7.6 & 12.2 & 12.3 & 1.5 & 35 & 130 & 15.5 & 5.2 & 62 \\
\hline Sunn hemp & 16 & 0.4 & 3.8 & 1.7 & 5.3 & 6.0 & 11.3 & 5.8 & 2.3 & 28 & 75 & 14.9 & 5.0 & 53 \\
\hline
\end{tabular}

In this case, there was a higher of carbon content and bases saturation value $(\mathrm{V} \%)$ in plots cropped with cover crops. It was also observed the highest cations values $\left(\mathrm{K}^{+}, \mathrm{Ca}^{2+}\right.$ and $\left.\mathrm{Mg}^{2+}\right)$, and the 
lowest potential acidity value $\left(\mathrm{H}^{+}+\mathrm{Al}^{3+}\right)$, which reflects in the lowest $\mathrm{pH}$ answer for the control. When soil organic matter is mineralized, and change organic material into organic and mineralized substance, there is an increase of both soil negative charges and pH (SARMENTO et al., 2008).

Significant increases in $\mathrm{pH}$, bases sum and bases saturation are results of residues production, and consequently, higher production of organic acids in their decomposition (ANDREOTTI et al., 2008). In addition, green manure residues, in general, have a high amount of cations in their tissues, related to the ability of plant residues on neutralizing soil acidity. Franchini et al. (1999) pointed out that the most important chemical changes, in 0-20 cm depth, are $\mathrm{pH}$ increase and $\mathrm{Ca}$ content since there is a decrease in Al. This action is attributed to formation of $\mathrm{Ca}$ fulvates as a result of organic material decomposition in an advanced stage. However, organic compounds of low molecular weight are predominant forms in initial decomposition period of plant residues. Their reaction in soil is characterized by fast and shortterm, focusing on the first two weeks after residue application (FRANCHINI et al., 1999).

The period after cover crops management was the only one, which was ideal in $\mathrm{pH}$ range to provide the greatest amount of nutrients for plants, from 5.5 to 6.5 (RAIJ, 2011). The $\mathrm{pH}$ variations may be related to changes in humic soil. In this trial, higher carbon content, the sum of humic substances and increase in $\mathrm{pH}$ were observed after cover crops management. This relationship is due to the acidic properties of organic chains of humic substances, which was conferred by their functional groups, especially carboxylic and phenolic groups. Since much of carboxylic groups dissociates to carboxylate anion, in $\mathrm{pH}$ values observed in most acidic soils $(5-7 \mathrm{pH})$, it is expected to have net negative charge in soil, and this affects soil cation exchange capacity - CEC (SILVA; MENDONÇA, 2007; RAIJ, 2011).

After maize harvest, the values of chemical soil analysis were similar. This may be related to changes in soil environment caused by its management, as the nutrients absorption by maize plant. In the previous period, there were a reduction of $\mathrm{pH}$, base saturation percentage, and potential acidity increase. Some leguminous can increase the soil acidification by carbon and nitrogen cycles
(BURLE et al., 1997). Moreover, the green mass of cover plants is under ongoing decomposition by microorganisms in organic acids, carbon dioxide and water to form carbonic acid, which in turn, reacts with calcium and magnesium carbonates in soil to form soluble bicarbonates, which are leached, consequently the soil becomes acid (LOPES, 1995).

Another factor to be considered is $\mathrm{Fe}$ reduction content after both cover crop management and maize harvest, in relation to the initial period, which may be related to organic matter addition on soil, which in turn, it is capable of forming organic complexes with $\mathrm{Fe}$. It may be strongly adsorbed by soil particles and forms complexes with humic acids and organic colloids (DECHEN; NACHTIGALL, 2006). Although $\mathrm{Fe}$ is found in greater quantities in soil, it is usually enough to crops. Certain factors such as amount of phosphates, copper, manganese, zinc and nickel, in acidic soils, can induce iron deficiency in plants (KIEHL, 2010). In this case, there was extra amount of manganese, which is considered high above $5 \mathrm{mg} \mathrm{dm}^{-3}$ (RAIJ, 2011). The similar results observed in control are related to the fact that, in this treatment, there was also an addition of plant material by weeds or environmental effects.

It was observed also increased soil cation exchange capacity. The occurrence of negatively charged sites responds to organic matter ability on retaining cations in sorption soil complex, which may reach up to $80 \%$ soil cation exchange capacity (FERREIRA et al., 2010). Still, in order to promote an increased CEC-dependent on $\mathrm{pH}$, organic matter benefits the adsorption of exchangeable cations $(\mathrm{Ca}$, $\mathrm{Mg}, \mathrm{K}$ ) by exchanges with $\mathrm{H}^{+}$of organic functional groups, increasing base saturation in colloidal complex (MUZZILI, 2012).

It is observed that the CEC and soil organic matter are closely correlated (Figure 1), since R value is equal to 0.94 , demonstrating that organic matter is an important contributor to CEC in this soil. This is because organic matter is adsorbed on kaolin and iron oxide. This interaction results in positive charges reduction, thereby, increases cation exchange capacity (MEURER et al., 2010). Organic matter contributes with 20-90\% CEC of surface layers from mineral soils (SILVA; MENDONÇA, 2007). Alleoni et al. (2009) also reported the existence of a significant correlation between CEC and organic matter. 


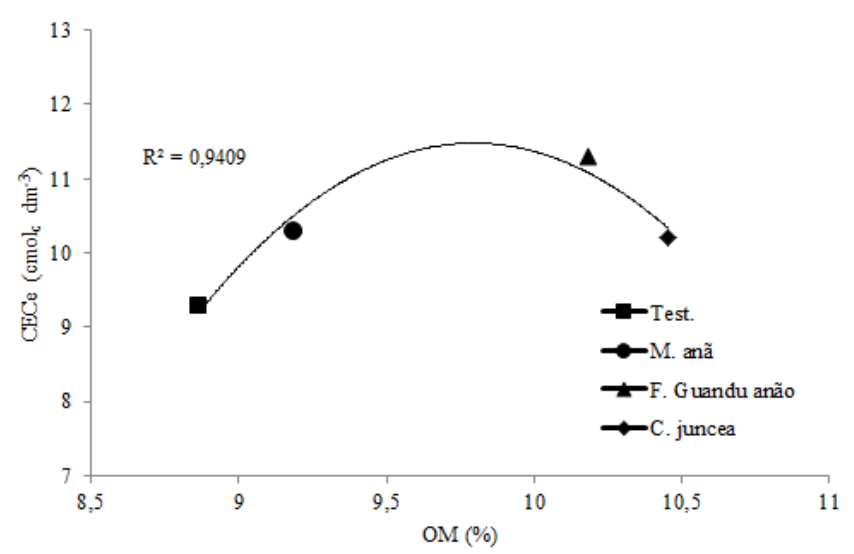

Figure 1. Correlation between cation exchange capacity (CEC) and soil organic matter (OM) after cover crops management.

The negative charges generated on $\mathrm{OM}$ surface by dissociation of functional groups (especially carboxyl - $\mathrm{COOH}$ ) are balanced by cations that are into soil solution. The connection between cations and organic surface is reversible (not specific), since it involves electrostatic nature interactions that are relatively weak (MEURER et al., 2010). Thus, according to the above authors, a particular ion, which is retained in the soil organic matter can be replaced by another one by stoichiometry. So many cations, essential to plant nutrition, can be readily available due to the easiness with which they are released into soil solution.
During the analysis of organic matter and $\mathrm{C}$ contents, collected at $0.10 \mathrm{~m}$ (Table 3 ), there was no statistical difference among treatments in the periods. It must be considered that the increase in the content of organic matter occurs gradually and its benefits are seen throughout the years (LOPES et al., 2004). This fact can be attributed to the fast decomposition of plant remains in tropical weather conditions (SOUZA NETO et al., 2008), which reduces the differential effects of cover crops to increase soil organic matter. Furthermore, the maintenance of the tillage residues can prevent soil $\mathrm{C}$ loss, instead of increasing C stocks (ZOTARELLI et al., (2012).

Table 3. Organic matter $(\mathrm{OM})$ and total carbon $(\mathrm{C})$ of soil before and after management with plants of dwarf mucuna (Mucuna deeringiana), pigeonpea dwarf (Cajanus cajan), sunn hemp (Crotalaria juncea) and weeds as the control and after maize harvest

\begin{tabular}{lllllll}
\hline & \multicolumn{2}{l}{ Before management } & \multicolumn{2}{l}{ After maize cropping } & \multicolumn{2}{l}{ After maize cropping } \\
\cline { 2 - 7 } & OM & $\mathrm{C}$ & $\mathrm{OM}$ & $\mathrm{C}$ & $\mathrm{OM}$ & $\mathrm{C}$ \\
\cline { 2 - 7 } Treatments & $---\%---$ & $--\mathrm{g} \mathrm{kg}^{-1}--$ & $---\%---$ & $--\mathrm{g} \mathrm{kg}^{-1}-$ & $---\%--$ & $--\mathrm{g} \mathrm{kg}^{-1}--$ \\
\hline Control & 10.61 & 61.74 & 8,85 & 51.51 & 9.41 & 54.72 \\
D. mucuna & 10.15 & 59.03 & 9,17 & 53.38 & 10.44 & 60.73 \\
P. dwarf & 10.86 & 63.21 & 10,44 & 60.76 & 10.06 & 58.55 \\
Sunn hemp & 10.61 & 61.73 & 10,17 & 59.19 & 11.63 & 67.68 \\
\hline Average & 10.90 & 63.43 & 9,66 & 56.21 & 10.38 & 60.42 \\
CV & 16.08 & 16.08 & 11,50 & 11.49 & 20.02 & 20.00 \\
F Value & $0.59^{\text {ns }}$ & $0.59^{\text {ns }}$ & $1,42^{\text {ns }}$ & $1.43^{\text {ns }}$ & $0.60^{\text {ns }}$ & $0.60^{\text {ns }}$ \\
\hline res followed by the same letters in column differ by Scott-Knott test at 5\% probability, with no significant ns; * Significant
\end{tabular}

Averages followed by the same letters in column differ by Scott-Knott test at $5 \%$ probability, with no significant ns; * Significant.

Similarly to this trial, Nascimento et al. (2005), in studies with cover crops, including the leguminous as Crotalaria juncea, Cajanus cajan and Stylozobium in Luvisol, found out that the use of leguminous, when compared to the control, remained unchanged soil organic carbon, soil bulk density and total porosity responses, among other factors. In this study, only total porosity showed different behavior after the cover crops management (Table 1). The fact that some analyzed characteristics like soil organic matter have not presented difference among cover crops, when compared to the control, may be related to the fact that the control has been a plot in fallow, i.e., the 
presence of spontaneous vegetation plus weeds, consequently that soil has not been uncovered.

During the analysis of organic matter fractions (Table 4), there was a predominance of humin fraction in all analyses. This can be related to the molecule size and the highest degree of stability of this fraction (FONTANA et al., 2006). The same authors have also stated that they show less stability, fulvic and humic acid fractions can be translocated to deeper soil layers, are polymerized or mineralized, and reduce its residual content in soil.

Table 4. Fractions of organic matter before and after management with plant dwarf mucuna (Mucuna deeringiana), pigeon pea dwarf (Cajanus cajan) and sunn hemp (Crotalaria juncea) and weeds in the control and after maize harvest

\begin{tabular}{|c|c|c|c|c|c|c|}
\hline \multirow[b]{2}{*}{ Treatments } & \multicolumn{6}{|c|}{ Before management } \\
\hline & FA & HA & $\mathrm{HU}$ & Sum & $\mathrm{HA} / \mathrm{FA}$ & $\mathrm{AE} / \mathrm{HU}$ \\
\hline & \multicolumn{4}{|c|}{----------------Mg g-1'-------------- } & & \\
\hline Control & 3.77 & 2.61 & 14.21 & 20,43 & 0,69 & 0,45 \\
\hline D. mucuna & 3.59 & 2.43 & 13.57 & 19,74 & 0,67 & 0,44 \\
\hline P. dwarf & 4.30 & 2.92 & 14.60 & 21,83 & 0,68 & 0,49 \\
\hline Sunn hemp & 3.56 & 2.39 & 15.45 & 21,40 & 0,67 & 0,38 \\
\hline Average & 3.81 & 2.59 & 14.45 & 20,81 & - & - \\
\hline $\mathrm{CV}$ & 18.49 & 26.04 & 9.36 & 7,97 & - & - \\
\hline \multirow[t]{3}{*}{ F Value } & $1.43^{\mathrm{ns}}$ & $0.79^{\mathrm{ns}}$ & $2.01^{\mathrm{ns}}$ & $2,05^{\mathrm{ns}}$ & - & - \\
\hline & \multicolumn{6}{|c|}{ After maize cropping } \\
\hline & FA & HA & $\mathrm{HU}$ & Sum & $\mathrm{HA} / \mathrm{FA}$ & $\mathrm{AE} / \mathrm{HU}$ \\
\hline & \multicolumn{4}{|c|}{-----------------mg g-1--------------- } & & \\
\hline Control & 4.30 & 2.51 & 13.36 & $20.02 \mathrm{~b}$ & 0.58 & 0.51 \\
\hline D. mucuna & 4.68 & 2.74 & 13.96 & $21.39 \mathrm{a}$ & 0.59 & 0.53 \\
\hline P. dwarf & 5.11 & 3.16 & 14.41 & $22.68 \mathrm{a}$ & 0.62 & 0.57 \\
\hline Sunn hemp & 4.71 & 2.77 & 14.40 & $21.85 \mathrm{a}$ & 0.59 & 0.51 \\
\hline Average & 4.70 & 2.79 & 14.45 & 21.49 & - & - \\
\hline $\mathrm{CV}$ & 10.00 & 20.86 & 9.36 & 5.53 & - & - \\
\hline \multirow[t]{4}{*}{ F Value } & $2.91^{*}$ & $1.25^{\mathrm{ns}}$ & $2.01^{\mathrm{ns}}$ & $5.30^{*}$ & - & - \\
\hline & \multicolumn{6}{|c|}{ After maize cropping } \\
\hline & FA & $\mathrm{HA}$ & $\mathrm{HU}$ & Sum & HA/FA & $\mathrm{AE} / \mathrm{HU}$ \\
\hline & \multicolumn{4}{|c|}{----------------mg g ${ }^{-1}$-------------- } & & \\
\hline Control & 4.16 & 2.70 & 13.36 & $19.89 \mathrm{~b}$ & 0.61 & 0.50 \\
\hline D. mucuna & 4.69 & 2.84 & 13.87 & $21.41 \mathrm{a}$ & 0.60 & 0.54 \\
\hline P. dwarf & 4.67 & 2.77 & 13.45 & $22.18 \mathrm{a}$ & 0.59 & 0.54 \\
\hline Sunn hemp & 4.55 & 3.01 & 14.30 & $21.94 \mathrm{a}$ & 0.66 & 0.52 \\
\hline Average & 4.52 & 2.83 & 13.74 & 21.11 & - & - \\
\hline $\mathrm{CV}$ & 8.74 & 16.14 & 8.32 & 4.96 & - & - \\
\hline F Value & $2.36^{\mathrm{ns}}$ & $0.48^{\mathrm{ns}}$ & $20.82^{\text {ns }}$ & $4.17^{*}$ & - & - \\
\hline
\end{tabular}

Averages followed by the same letters in column differ by Scott-Knott test at 5\% probability, with no significant ns; * Significant. . FA: fulvic acid fraction; HA: humic acid fraction; HU: humin; EA: alkaline extract.

Also, the most common organic fraction of tropical soils is humin and the intense mineralization of residues, such as soil restrictions on biological activity, reduces humification process (CANELLAS et al., 2000). Moreover, the inclusion of leguminous as green manure provides organic nitrogen used mainly by microorganisms that synthesize more stable fractions of soil organic matter (humin).

Loss, Pereira and Brito (2006) also found out higher carbon content in humin fraction, mainly for Oxisols, which, according to the authors, suggest the highest resistance of this fraction to decomposition, due to more stable connection with the mineral fraction of soil. Canellas and Façanha (2004) studied chemical nature of humified fractions and also recorded that the distribution of humified organic matter is typical of tropical soils. Such fractions also presented the highest humic substances content of soluble alkali, which are more condensed on soil surface. 
Before the trial implementation, there were no statistical differences among plots in each fraction. On the other hand, after both cover crops management and maize harvest, it was observed that plots cropped with these plants showed the highest carbon content when the three fractions were summed. The organic matter synthesis is slow, but fluctuations in the relative content of its fractions express effective changes for a long time. In other words, it is a stable and conservative indicator. Only significant changes in the system under study will be reflected in the distribution of organic matter humified components (CUNHA et al., 2005).

The condensation of organic matter soluble is indicated by $\mathrm{HA} / \mathrm{FA}$ ratio (LABRADOR MORENO, 1996). According to the author, values inferior to 1 , as presented in this paper, represent the great majority of fulvic acid fractions in relation to humic acid fraction. This indicates a limited progress of organic matter due to edaphic characteristics or soil management and recent organic matter addition. The fulvic acid fraction is associated to the least evolved fraction, which is also related to acidic reaction (CUNHA et al., 2005). Further, the fraction separation methodology, used in this study, the FA fraction gathers both true fulvic acids and low molecular weight compounds such as organic acids, sugars, and others. Canellas and Façanha (2004) found out lower HA/FA ratios in soil cropped with leguminous in order to highlight a fulvic character of humic substances when leguminous are cropped. In the same experimental area, in the analysis of the humic substances, it was observed that there was an increase in their content during the experiments, confirming the increase of OM content in the plots cultivated with cover plants (ROSA et al, 2017).

In general, the low content of exchangeable cations in highly weathered soils, as well as in the soil, reduces the intensity of humification process (condensation and synthesis), as a result, the HA/FA ratio is smaller (CUNHA et al., 2005; CANELLAS et al, 2002). Generally, in Oxisol, there is a decrease in humic acid content and predominance of fulvic acids as it was observed in this study. This may be related to the presence of oxides and kaolinite in these soils. The humic acid fraction can be decomposed more easily than fulvic acid that favors the occurrence of reactive fractions that are easily consumed by microorganisms. The adsorption of organic matter to oxides is influenced by carboxyl groups, most abundant in fulvic acids, consequently they are more resistant to decomposition (CUNHA et al., 2005). Also in weathered soils, the predominance of fulvic acids can be explained by fast transformation of organic residue and the complexation of these fractions by $\mathrm{Fe}$ and $\mathrm{Al}$ oxides (CANELLAS et al., 2005).

There was, between periods, a decrease of HA/FA ratio, which may be associated to recent addition of plant material that increases initially the fulvic acids content. According to Silva and Mendonça (2007), fulvic acids are the group with the lowest molecular weight and highest density of carboxylic groups. This shows greater solubility and polarity than humic acids; thus, higher mobility in soil. However, in a long term, the highest prevalence of fulvic acids may result in organic matter loss via percolated water.

Canellas et al. (2004) evaluated the changes in content and quality of organic matter in a redyellow Argisol, in Rio de Janeiro, with perennial herbaceous leguminous cropping. The authors observed qualitative changes in management of vegetable residue, wherein the permanent soil coverage with leguminous gave higher condensation degree of humic acids. Although, they did not registered quantitative differences.

It should be noted that the effectiveness of crop rotation in agriculture is proven by research results, being feasible and essential for yield sustainability. The benefits have provided some improvements of chemical, physical and biological qualities on soil, as well as a reduction on pests, diseases and weeds, consequently, there is an improvement on crop yields. Thus, farmers must face crop rotation as an investment that will result in benefits in a medium and long term.

\section{CONCLUSIONS}

The cover crops may need more time to express their potential, mainly related to the soil physical characteristics, although the observed variation of total porosity and macroporosity.

The chemical properties are influenced by the applied management, since major changes were observed after management with cover crops.

Even though this crop rotation have not provided significant increase in soil Carbon content, in long term, it may allow the soil quality maintenance, indicated by changes in the total sum of fractions of humic substances, in order to prevent nutrients and carbon loss. 
RESUMO: A rotação de culturas é ação básica para garantir a viabilidade do sistema plantio direto, porém, é pouco aceita e praticada pelos agricultores. Assim, este trabalho teve por objetivo estabelecer o esquema de rotação de culturas sobre a qualidade do solo. Para isso, sob sistema plantio direto, foram implantadas, em 2010, as plantas de cobertura mucuna anã, feijão guandu anão, crotalaria juncea, e a cultura do milho. As propriedades do solo foram determinadas anteriormente à implantação, após o manejo da cobertura vegetal e após a colheita do milho. Os resultados encontrados foram submetidos à análise de variância e a comparação de médias. As plantas de cobertura podem precisar de mais tempo para que expressem seu potencial, principalmente relacionado às características físicas do solo, embora tenha sido observada variação da porosidade total e macroporosidade. As propriedades químicas são sensíveis ao manejo empregado, já que maiores alterações foram observadas após o manejo com as plantas de cobertura. Mesmo que não possibilite aumento significativo no teor de $\mathrm{C}$ no solo, o uso desta rotação, em longo prazo, poderá permitir a manutenção da qualidade do solo, evitando perdas de nutrientes e carbono.

PALAVRAS-CHAVE: Rotação de culturas. Substâncias húmicas. Zea mays. Mucuna deeringiana. Cajanus cajan. Crotalaria juncea.

\section{REFERENCES}

ALLEONI, L. R. F.; CAMARGO, O. A.; CASAGRANDE, J. C.; SOARES, M. R. Química dos solos altamente intemperizados. In: MELLO, V. F.; ALLEONI, L. R. F. Química e mineralogia do solo. Viçosa, SBCS, 2009, p. 381-448, 2009.

AMBROSANO, E. J.; GUIRADO, N.; ANTARELLA, H.; SETO, R.; MENDES, P.C.D.; ROSSI, F.; AMBROSANO, G. M. B.; SCHAMMAS, E.A.; JUNIOR, I. A.; FOLTRAN, D. E. Plantas para cobertura do solo e adubação verde aplicadas ao plantio direto. Informações Agronômicas, Piracicaba, Potafos (112), 1-16, 2005.

BENITES, V. M.; MADARI, B.; MACHADO, P. L. O. A. Extração e fracionamento quantitativo de substâncias húmicas do solo: um procedimento simplificado de baixo custo. Rio de Janeiro, Embrapa, 7 p. (Comunicado Técnico 16), 2003.

BURLE, M. L.; MIELNICZUC, J.; FOCCHI, S. Effect of cropping on soil chemical characteristics with emphasis on soil acidification. Plant and Soil, v. 190, n. 2, 309-316, 1997.

https://doi.org/10.1023/A:1004266831343

CALEGARI, Ademar. Plantas de cobertura. In: CASÃO JUNIOR, R. et al. Plantio direto com qualidade. Londrina: IAPAR; Foz do Iguaçu: ITAIPU Binacional, 55-73, 2006.

CANELLAS, L. P.; BUSATO, J. G.; CAUME, D. J. O uso e o manejo da matéria orgânica humificada sob a perspectiva da agroecologia. In: CANELLAS, L. P.; SANTOS, G.A. Humosfera: tratado preliminar sobre a química das substâncias húmicas, UENF, Rio de Janeiro, 244-267, 2005

CANELLAS, L. P.; FAÇANHA, A. R. Chemical nature of soil humified fractions and their bioactivity. Pesquisa Agropecuária Brasileira, v. 39, n. 3, 233-240, 2004 . https://doi.org/10.1590/S0100204X2004000300005

CANELLAS, L. P.; VELlOSO, A. C. X.; RUMJANEK, V.M.; GURIDI, F.; OLIVARES, F. L.; SANTOS, G. A.; BRAZ-FILHO, R. Distribuition of the humified fractions and characteristics of the humic acids of an ultisol under cultivation of Eucalyptus and sugar cane. Terra, v. 20, n.1, p. 371-381, 2002.

CANELLAS, L. P.; BERNER, P. G.; SILVA, S.G.; SIVA, M. B.; SANTOS, G. A. Fração da matéria orgânica em seis solos de uma topossequência no Estado do Rio de Janeiro. Pesquisa Agropecuária Brasileira, v. 35 , n. 1, 133-143, 2000. https://doi.org/10.1590/S0100-204X2000000100016 
COSTA, C. H. M.; CRUSCIOL, C. A. C.; SORATTO, R. P.; FERRARI NETO, J. Phytomass decomposition and nutrients release from pearl millet, guinea grass and palisade grass. Bioscience Journal, Uberlândia, v. 32, n. 5, p. 1191-1203, 2016. https://doi.org/10.14393/BJ-v32n5a2016-32982

CUNHA, T. F.; CANELLAS, L. P.; SANTOS, G. A.; RIBEIRO, L. P. Fracionamento da matéria orgânica humificada de solos brasileiros. In: CANELLAS, L. P.; SANTOS, G.A. Humosfera: tratado preliminar sobre a química das substâncias húmicas. Rio de Janeiro: UENF, 54-80, 2005.

DECHEN, A. R.; NACHTIGALL, G. R. Micronutrientes. In: FERNANDES, M.S. Nutrição mineral de plantas. Viçosa: SBCS, 327-354, 2006.

Empresa Brasileira De Pesquisa Agropecuária - EMBRAPA. Centro Nacional de Pesquisas de Solos. Manual de métodos de análise de solo. 2 ed. Rio de Janeiro, 1997. 221 p.

FERREIRA, R. R. M.; TAVARES FILHO, J.; FERREIRA. V. M. Efeitos de sistemas de manejo de pastagens nas propriedades físicas do solo. Semina: Ciências Agrárias, v. 31, n. 4, 913-932, 2010.

https://doi.org/10.5433/1679-0359.2010v31n4p913

FONTANA, A.; PEREIRA, M. G.; LOSS, A.; CUNHA, T. J. F.; SALTON, J. C. Atributos de fertilidade e frações húmicas de um latossolo vermelho no cerrado. Pesquisa Agropecuária Brasileira, v. 41, n. 5, 847853, 2006. https://doi.org/10.1590/S0100-204X2006000500018

FRANCHINI, J. C.; COSTA, J. M.; DEBIASI, H.; TORRES, E. Importância da rotação de culturas para a produção agrícola sustentável no Paraná. Londrina: Embrapa Soja, 2011. 52 p (Documentos, 327).

FRANCHINI, J. C.; MIYAZAWA, M.; PAVAN, M. A.; MALAVOLTA, E. Dinâmica de íons em solo ácido lixiviado com extratos de resíduos de adubos verdes e soluções puras de ácidos orgânicos. Pesquisa Agropecuária Brasileira, v. 34, n. 12, 2267-2276, 1999. https://doi.org/10.1590/S0100-204X1999001200014

Kiehl, E. J. Novo fertilizantes orgânicos. Piracicaba: Degaspari, 2010. 248 p.

KIEHL, E. J. Manual de edafologia. São Paulo: Agronômica Ceres, 1979. 263 p.

KLEIN, V. A. Densidade relativa - um indicador da qualidade física de um latossolo vermelho. Revista de Ciências Agroveterinárias, v. 5, n. 1, 26-32, 2006.

LABRADOR MORENO, J. La matéria orgánica en los agrosistemas. Madri: Ministéria Agricultura, 1996. $176 \mathrm{p}$.

LOPES, S. A.; WIETHÕLTER, S.; GUILHERME, L. R. G.; SILVA, C. A. Sistema plantio direto: bases para o manejo da fertilidade do solo. São Paulo: Associação Nacional para Difusão de Adubos - ANDA, 2004, $110 \mathrm{p}$.

LOPES, A. S. Manual internacional de fertilidade do solo. Piracicaba: Potafos, 1995. 177p.

LOSS, A.; PEREIRA, M. G.; BRITO, R. J. Distribuição das substâncias húmicas em solos de tabuleiros sob diferentes coberturas vegetais. Revista Universidade Rural, v. 26, n. 1, 57-69, 2006.

MAZURANA, M.; Levien, R.; Inda Junior, A. V.; Conte, O.; Bressani, L. A.; Müller, J. Soil susceptibility to compaction under use conditions in southern Brazil. Ciência e Agrotecnologia, v. 41, n. 1, 60-71, 2017. ttps://doi.org/10.1590/1413-70542017411027216

MEURER, E. J.; RHEINHEIMER, R. D.; BISSANI, C. A. Fenômenos de sorção em solos. In: MEURER, E. J. Fundamentos de química do solo. Porto Alegre: Evangraf, 2010. 266 p. 
MIYASAKA, S.; NAGAI, K.; SAKITA, M. N.; MIYASAKA, N. S. Manejo da biomassa e de solo visando à sustentabilidade da agricultura brasileira. São Paulo: FUNDAG, 2008. 192 p.

MINGOTTE, F. L. C.; YADA, M. M.; JARDIM, C. A.; FIORENTIN, C. F.; LEMOS, L. B.; FORNASIERI FILHO, D. Sistemas de cultivo antecessores e doses de nitrogênio em cobertura no feijoeiro em plantio direto. Bioscience Journal, v. 30, supplement 2, p. 696-706, 14.

MUZILLI, O. (2003) - Manejo da matéria orgânica no sistema plantio direto: a experiência no estado do Paraná. Disponível em: http://www.ppifar.org/ppiweb/pbrazil.nsf. Acesso em: out. 2012.

NASCIMENTO, J. T.; SILVA, I. F.; SANTIAGO, R. D.; SILVA NETO, L. F. Efeitos de leguminosas nos atributos físicos e carbono orgânico de um Luvissolo. Revista Brasileira de Ciência do Solo, Viçosa, v. 29, n. 1, 825-831, 2005. https://doi.org/10.1590/S0100-06832005000500018

RAIJ, B. V. Fertilidade do solo e manejo de nutrientes. Piracicaba: International Plant Nutrition Institute, 2011. 420 p.

REINERT, D. J.; ALBUQUERQUE, J. A.; REICHERT, J. M.; AITA, C.; ANDRADA, M. M. C. Limites críticos de densidade do solo para o crescimento de raízes de plantas de cobertura em Argissolo Vermelho. Revista Brasileira de Ciência do Solo, v. 32, n. 5, 1805-1816, 2008. https://doi.org/10.1590/S010006832008000500002

ROSA, D. M.; NÓBREGA, L. H. P.; MAULI, M. M.; LIMA, G. P.; PACHECO, F. P. Substâncias húmicas do solo cultivado com plantas de cobertura em rotação com milho e soja. Revista Ciência Agronômica, v. 48, n. 2, 221-230, 2017.

ROSA, D. M.; NÓBREGA, L. H. P.; MAULI, M. M.; LIMA, G. P.; BOLLER, W. Weeds suppression and agronomic characteristics of maize crop under leguminous crop residues in no-tillage system. Tropical and Subtropical Agroecosystems, v. 16, 455-463, 2013.

ROSA, D. M.; NÓBREGA, L. H. P.; LIMA, G. P.; MAULI, M. M.; COELHO, S. R. M. Action of dwarf mucuna, pigean pea and stylosanthes on weeds under Field and laboratory conditions. Interciencia, v. 36, n. 11, 841-847, 2011.

SARMENTO, P.; RODRIGUES, L. R. A.; CRUZ, M. C. P.; LUGÃO, S. M. B.; CAMPOS, F. P.;

CENTURION, J.; FEREIRA, M. E. Atributos químicos e físicos de um argissolo cultivado com Panicum maximum Jacq. cv. IPR-86 Milênio sob lotação rotacionada e adubado com nitrogênio. Revista Brasileira de Ciência do Solo, v. 32, n. 1, 183-193, 2008. https://doi.org/10.1590/S0100-06832008000100018

SILVA, I. R.; MENDONÇA, E. S. Matéria Orgânica Do Solo. In: NOVAIS, R. F. et al. Fertilidade do solo. Viçosa - MG: Sociedade Brasileira de Ciência do Solo, 2007, 1017 p.

SOUZA NETO, E. L.; ANDRIOLI, I.; BEUTLER, A. N.; CENTURION, J F. Atributos físicos do solo e produtividade de milho em resposta a culturas de pré safra. Revista Brasileira de Ciência do Solo, v. 43, n. 2 , 255-260, 2008. https://doi.org/10.1590/S0100-204X2008000200015

ZOTARELLI, L.; ZATORRE, N. P.; BODDEY, R. M.; URQUIAGA, S.; JANTALIA, C. P.; FRANCHINI, J. C.; ALVES, B. J. R. Influence of no-tillage and frequency of a green manure legume in crop rotations for balancing N outputs and preserving soil organic C stocks. Field Crops Research, v. 132, 185-195, 2012. https://doi.org/10.1016/j.fcr.2011.12.013 